Proc. Estonian Acad. Sci. Biol. Ecol., 2001, 50, 2, 110-129

\title{
HISTORY OF HYDROGRAPHIC RESEARCH IN SWEDEN
}

\author{
Stig FONSELIUS
}

\author{
SMHI Oceanographic Laboratory, Nya Varvet 31, SE-426 71 Västra Frölunda, Sweden; \\ fonselius@ swipnet.se
}

Received 28 March 2001

\begin{abstract}
Hydrographic investigations in the 18th and 19th centuries are briefly described. An extensive investigation of the Baltic Sea was performed in 1877. Regular observations of temperature, salinity, and currents were started on Swedish lightships and coastal stations in 1878 . The different hydrographic organizations and scientists are presented. In 1893 the Swedish Hydrographic Commission, from 1902 the Hydrographic-Biological Commission, was formed. The complicated relations between the Oceanographic Institution at the University of Göteborg, the Oceanographic Institute, and the Hydrographic-Biological Commission are explained. Some worldfamous oceanographers and their works are presented. The Commission was dissolved in 1948 and the Board of Fisheries of Sweden was formed, taking over its responsibilities. The hydrographic investigations were assigned to the Hydrographic Department of the Board of Fisheries. The development of the Hydrographic Department and its transfer to the Swedish Meteorological and Hydrological Institute are described. The work of the Fisheries Bureau and the Navy Hydrographic Office are briefly explained.
\end{abstract}

Key words: hydrography, Hydrographic-Biological Commission, Hydrographic Department, SMHI Oceanographic Laboratory, Oceanographic Institution, Oceanographic Institute, Board of Fisheries, research vessels, leading scientists, Baltic Sea.

\section{EARLY SWEDISH HYDROGRAPHIC OBSERVATIONS}

The oldest Swedish observations on the properties of the water itself were made by Wilcke (1771), who also constructed a deepwater sampler (Fig. 1), and by Bladh (1776), who measured the density and temperature of the sea water 
in the Öresund, at different points on the Swedish Baltic Sea coast, in the Åland Sea, and in the Gulf of Bothnia. The Swedish scientist Bergman (1788) analysed sea water. He reported the following components: common salt, salinited magnesia (magnesium chloride), and loose gypsum. He also observed that sea water was slightly alkaline. In earlier times the density of sea water was used for salinity determinations with different kinds of hydrometers.

Nordenanckar (1795) presented a paper on the currents in the Baltic Sea. The current observations were made during many years. Cronander (1898) carried out current observations on Danish and Swedish lightships. He constructed a current meter and measured currents in the Baltic Sea and in the Öresund on board lightships and also smaller boats. He calculated

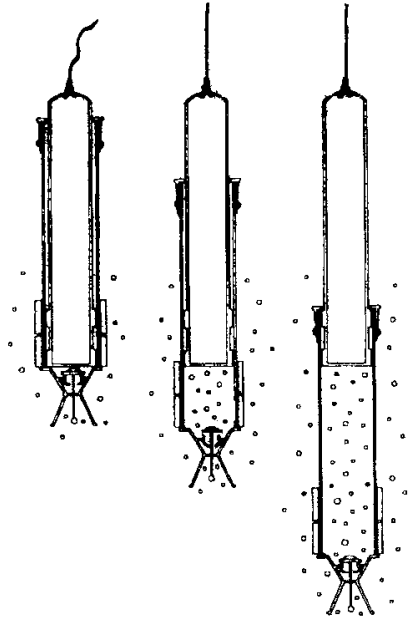

Fig. 1. Piston water sampler constructed by Wilcke in 1771 (Svansson, pers. comm., 2000). the annual mean ingoing and outgoing currents through the Belts and the Sound based on current observations on board the lightships Schulz Grund and Drogden. He compared current data collected on the Drogden from 1850-59 and 1864-73. The current observations did not cover the whole year and therefore the conclusions were uncertain.

\section{THE SWEDISH HYDROGRAPHIC EXPEDITIONS IN THE BALTIC SEA IN SUMMER 1877}

Fredrik L. Ekman, professor of physics at the Stockholm High School (University), started hydrographic investigations in Swedish waters in 1869. He was joined by A. W. Cronander and Gustaf Ekman. In 1875 Prof. F. L. Ekman and Prof. Sven Lovén suggested to the Royal Academy of Sciences that hydrographic, zoological, and biological expeditions should be carried out in the seas around Sweden. The Parliament provided 10000 kronas for the purpose and the Government made the necessary steamers available (Fonselius, 2001).

Only the hydrographic expedition in the Baltic Sea was carried out in the summer of 1877 (Map 1). The work consisted of two parts, one with the gunboat Alfhild covering the Skagerrak, Kattegat, and the Baltic Proper up to the island of Gotland. The chief scientist on board was Prof. Ekman. 


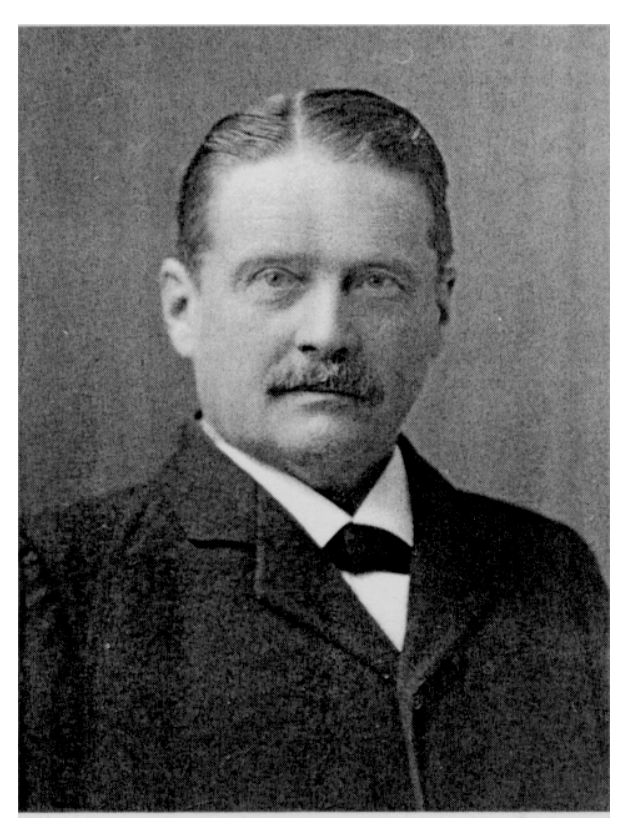

Fig. 2. Professor Otto Pettersson (1848-1941).

The number of stations amounted to 96 . The second part of the cruise was carried out with the survey ship G. af Klint and it covered the Gulf of Bothnia, the Aland Sea, the mouth of the Gulf of Finland, and the northern Baltic Proper. Participating scientists were F. S. Malmberg and A. W. Cronander. Altogether 112 stations were visited. An isolated water sampler was used for temperature measurements on board the Alfhild. On the G. af Klint Miller-Casella maximum-minimum thermometers were mainly used (Ekman, 1893). A minimum temperature layer below the warm surface water was discovered. This layer caused much speculations. The background of its origination was

the vertical convection of the surface water in winter and warming of this water during spring and summer. Cold surface water from the previous winter was preserved between the thermocline and the halocline.

After the death of Prof. Ekman, Otto Pettersson, professor of chemistry at the University of Stockholm (Fig. 2), worked out and published the Swedish results and compared these with the results of the German Pommerania expedition of 1871. He found that the results were generally similar in the southern part of the Baltic Proper. At the Landsort Deep the difference between the German and Swedish results was large and Pettersson concluded that extensive changes in the deep water had occurred between 1871 and 1877 (Table 1). The Swedish expeditions in 1877 were the most important and detailed investigations in the Baltic Sea during the 19th century (Pettersson, 1893). Prof. Pettersson published a large number of scientific papers in oceanography and became a world-famous oceanographer. He is considered the father of oceanography in Sweden.

\section{THE BEGINNING OF SWEDISH REGULAR HYDROGRAPHIC INVESTIGATIONS IN THE BALTIC SEA}

In 1878 a nautical-meteorological conference on continuous hydrographic measurements on ships on regular routes, lightships, and coastal stations was 


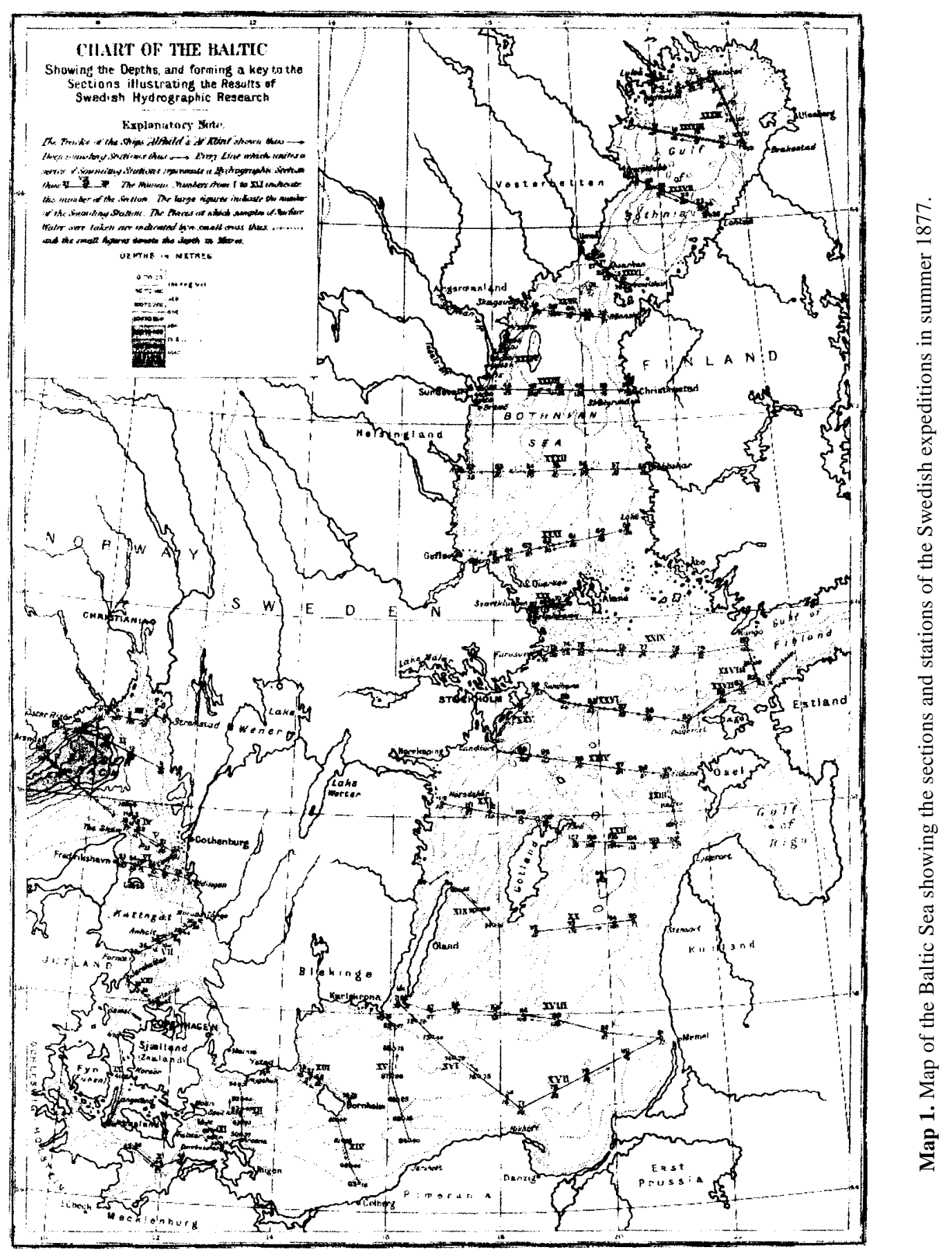


Table 1. Landsort Deep: results of four expeditions

\begin{tabular}{|c|c|c|c|c|c|c|c|c|c|c|c|}
\hline \multirow{2}{*}{$\underset{\mathrm{m}}{\text { Depth, }}$} & \multicolumn{2}{|c|}{ Pommerania, 1871} & \multicolumn{2}{|c|}{ F. L. Ekman, 1877} & \multicolumn{3}{|c|}{ O. Pettersson, 1891} & \multicolumn{4}{|c|}{ Swedish Commission, 1893} \\
\hline & Salinity, \%o & Temp., ${ }^{\circ} \mathrm{C}$ & Salinity, \%o & Temp., ${ }^{\circ} \mathrm{C}$ & Salinity, \%o & Temp., ${ }^{\circ} \mathrm{C}$ & $\mathrm{O}_{2}, \mathrm{~cm}^{3} / \mathrm{L}$ & Salinity, \%o & Temp., ${ }^{\circ} \mathrm{C}$ & $\mathrm{O}_{2}, \mathrm{~cm}^{3} / \mathrm{L}$ & $\mathrm{CO}_{2}, \mathrm{~cm}^{3} / \mathrm{L}$ \\
\hline 0 & 6.46 & 13.6 & 6.13 & 15.4 & - & 10.4 & - & 6.52 & 13.55 & - & - \\
\hline 10 & - & - & 6.60 & 11.3 & - & - & - & 6.63 & 13.65 & 8.17 & - \\
\hline 20 & - & - & 6.54 & 3.9 & - & 8.00 & - & 6.78 & 7.85 & - & - \\
\hline 30 & - & - & 7.12 & 2.0 & - & 5.05 & - & 7.08 & 4.00 & - & - \\
\hline 40 & - & - & 7.48 & 2.1 & - & - & - & 7.12 & 3.25 & - & - \\
\hline 50 & 9.12 & 3.0 & 7.48 & - & - & 3.00 & - & 7.35 & 2.35 & 8.58 & 32.31 \\
\hline 60 & - & - & 7.62 & 2.3 & - & 2.60 & - & 7.84 & 2.10 & 6.67 & 33.73 \\
\hline 70 & - & - & - & - & - & 2.80 & - & - & - & - & - \\
\hline 80 & - & - & 9.52 & 3.4 & - & 3.10 & - & 9.43 & 3.45 & - & - \\
\hline 100 & - & - & 9.52 & - & - & 3.30 & 4.41 & 9.86 & 4.80 & 3.09 & 38.26 \\
\hline 110 & - & 2.8 & - & - & - & - & - & - & - & - & - \\
\hline 120 & - & - & 10.48 & 3.7 & - & 3.60 & - & 10.04 & 3.75 & - & - \\
\hline 140 & - & - & 10.41 & - & - & - & - & 10.09 & 3.85 & - & - \\
\hline 160 & 9.20 & 2.2 & 10.20 & 3.7 & - & - & - & - & - & - & - \\
\hline 180 & - & - & 10.28 & - & - & - & - & - & - & - & - \\
\hline 200 & 9.96 & 0.8 & 10.35 & 3.7 & - & 3.70 & - & 10.22 & 3.90 & 2.73 & 38.36 \\
\hline 220 & - & - & 10.35 & 3.7 & - & - & - & - & - & - & - \\
\hline 240 & - & - & 10.41 & 3.7 & - & - & - & 10.32 & 3.90 & - & - \\
\hline 260 & - & - & 10.45 & 3.7 & - & - & - & 10.32 & 3.90 & - & - \\
\hline 280 & - & - & 10.48 & 3.7 & - & - & - & 10.32 & 3.95 & - & - \\
\hline 300 & - & - & 10.48 & 3.7 & - & 3.70 & 3.51 & 10.32 & 3.85 & 2.82 & - \\
\hline 320 & - & - & 10.51 & 3.8 & - & - & - & 10.32 & 3.85 & - & - \\
\hline 340 & - & - & 10.51 & 3.7 & - & - & - & - & - & - & - \\
\hline 360 & - & - & 10.54 & 3.8 & - & 3.75 & 3.04 & 10.34 & - & - & - \\
\hline 380 & - & - & 10.61 & 3.9 & - & - & - & 10.36 & - & - & - \\
\hline 400 & - & - & 10.73 & 4.6 & - & 3.8 & 3.19 & 10.36 & 3.90 & 1.33 & 40.65 \\
\hline 411 & - & - & - & - & - & 3.8 & 3.21 & - & - & - & - \\
\hline
\end{tabular}


held in Copenhagen with participants from Denmark, Norway, and Sweden. Measurements and observations of different parameters in air and water were discussed (Anon., 1878).

Prof. F. L. Ekman reported during the meeting on the Swedish activities (Anon., 1878, appendix). He suggested the use of a common log for surface current measurements. Instructions for hydrographic measurements on Swedish lighthouses and pilot stations (Anon., 1879) were published, which were also adopted in Denmark. Reversing thermometers without auxiliary thermometers and water samplers, which were closed by means of a propeller device or by messengers, were used (Fig. 3). The salinity was determined from density measurements with a hydrometer. A current meter constructed by Th. Arwidsson was used for deep measurements. Otto Pettersson worked out methods to determine oxygen and carbon dioxide by gasometric analysis and reported values from some of the main deep stations in the Baltic Proper.

Prof. Pettersson compared his measurements in the Landsort Deep from 1891 and the Swedish results from 1893 with Ekman's results from 1877 and found that the water from the depth of $150 \mathrm{~m}$ down to the bottom at $400 \mathrm{~m}$ had nearly the same temperature and salinity (Table 1). Unfortunately the salinity measurements from 1891 had been lost, but before that a diagram showing the salinity distribution had been drawn. A similar diagram from the 1893 expedition gave nearly the same distribution. The oxygen content had decreased around $30 \%$ from 1891 to 1893 and the carbon dioxide had increased proportionally. He concluded that water with higher density occasionally streamed in along the bottom and filled the deep basins. This water caused stagnation for many years. The oxygen content in the stagnant basins decreased through oxidation of dead organic matter and carbon dioxide was formed. It is admirable that Prof. Pettersson could draw the right conclusions from very few and partly questionable data.

For the first time cooperation between hydrographers from different countries was established with the aim to carry out a rational investigation of the Baltic Sea. At the 14th Scandinavian science meeting in Copenhagen (Anon., 1892), a resolution on international cooperation suggested by Pettersson was adopted. In that year the Danish and Swedish hydrographic commissions were established and in both countries hydrographic-biological investigations were started.

In 1897 O. Pettersson and G. Ekman had come to the conclusion that track could be kept of the state and variations of the Baltic Sea by measuring hydrographic data only on a few deep stations. It should therefore be easy to follow these variations from season to season and year to year by measuring the main hydrographic parameters regularly on the main stations (Pettersson \& Ekman, 1897). In the Baltic Sea we therefore have temperature and salinity observations at the major deep stations from around 1890 . 

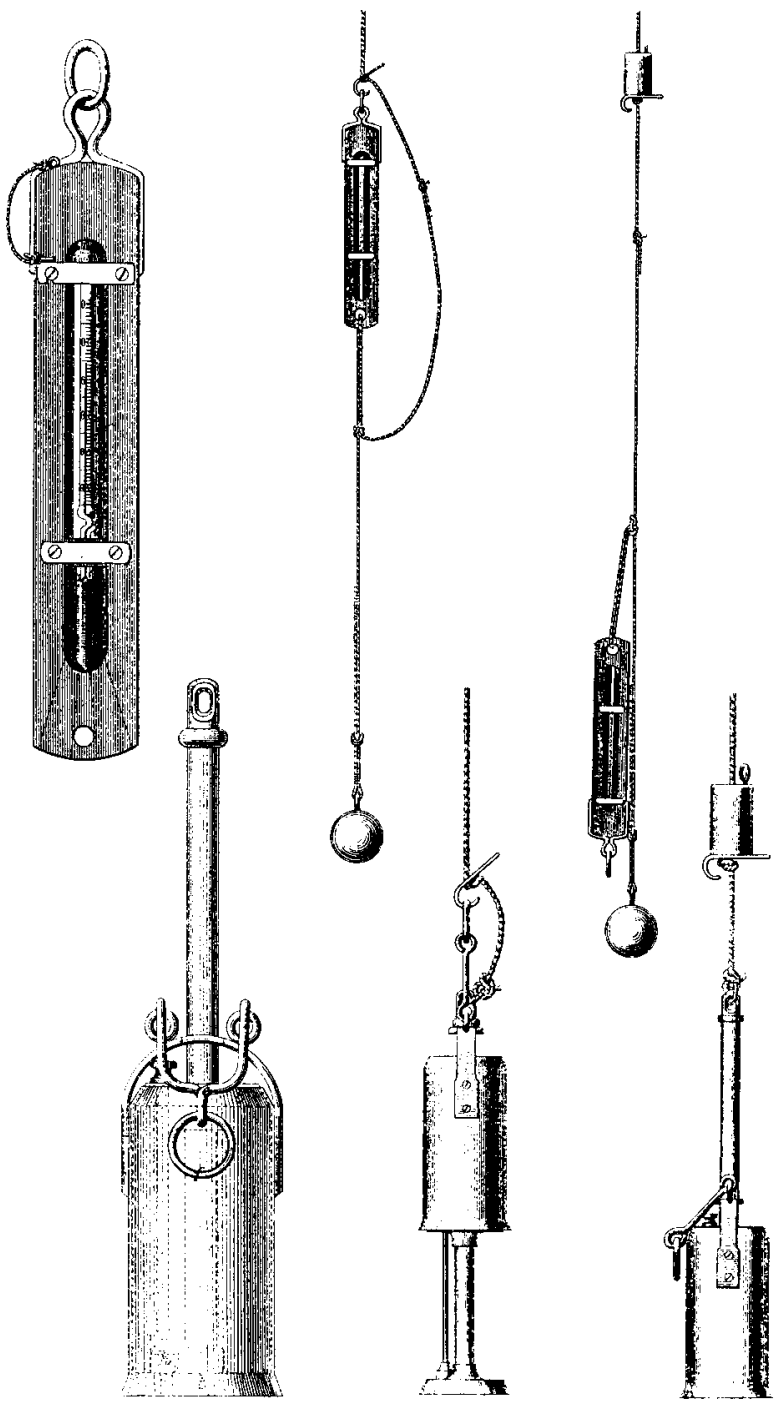

Fig. 3. Reversing thermometer and water sampler used on Swedish lightships in 1879.

\section{THE HYDROGRAPHIC-BIOLOGICAL COMMISSION}

A commission, called the Hydrographic Commission, was formed in 1893, consisting of Mr. G. Ekman, Prof. O. Pettersson, and Prof. E. A. Wijkander. The Commission immediately secured cooperation with the biologists professors C. W. S. Aurivillius and P. T. Cleve. In 1901 the Commission was changed 
to the Hydrographic-Biological Commission (HBC) with Count G. Lagerbring (chairman), Prof. P. T. Cleve, Mr. G. Ekman, Prof. O. Pettersson, Prof. E. A. Wijkander, and first fisheries inspector F. Trybom as members. At the Scandinavian science meeting in Stockholm in July 1898 it was agreed between the Danish, Finnish, and Swedish hydrographers that simultaneous investigations should be carried out regularly in different parts of the Baltic Sea. Cooperation between the Scandinavian countries and Germany obviously gave Prof. Pettersson the idea of a larger cooperation between European countries and the founding of the International Council for the Exploration of the Sea (ICES).

In 1901 the Bornö Hydrographic Station on an island in the Gullmarsfjord (Fig. 4) was founded with donations from Prof. O. Pettersson and Mr. G. Ekman. The Bornö Station was bought and modernized by the Swedish Government in 1935. Daily salinity observations were made there until the 1980s with the help of a gold chain hydrometer. The hydrographic and biological laboratories of the Commission worked on the Bornö Station until 1929, when the biologists moved to the new Biological Laboratory in Lysekil. In 1904 the Commission got the research ship Skagerak.

Otto Pettersson discovered the internal waves in the boundary layer between brackish surface water and ocean water in the Kattegat by studying the variations

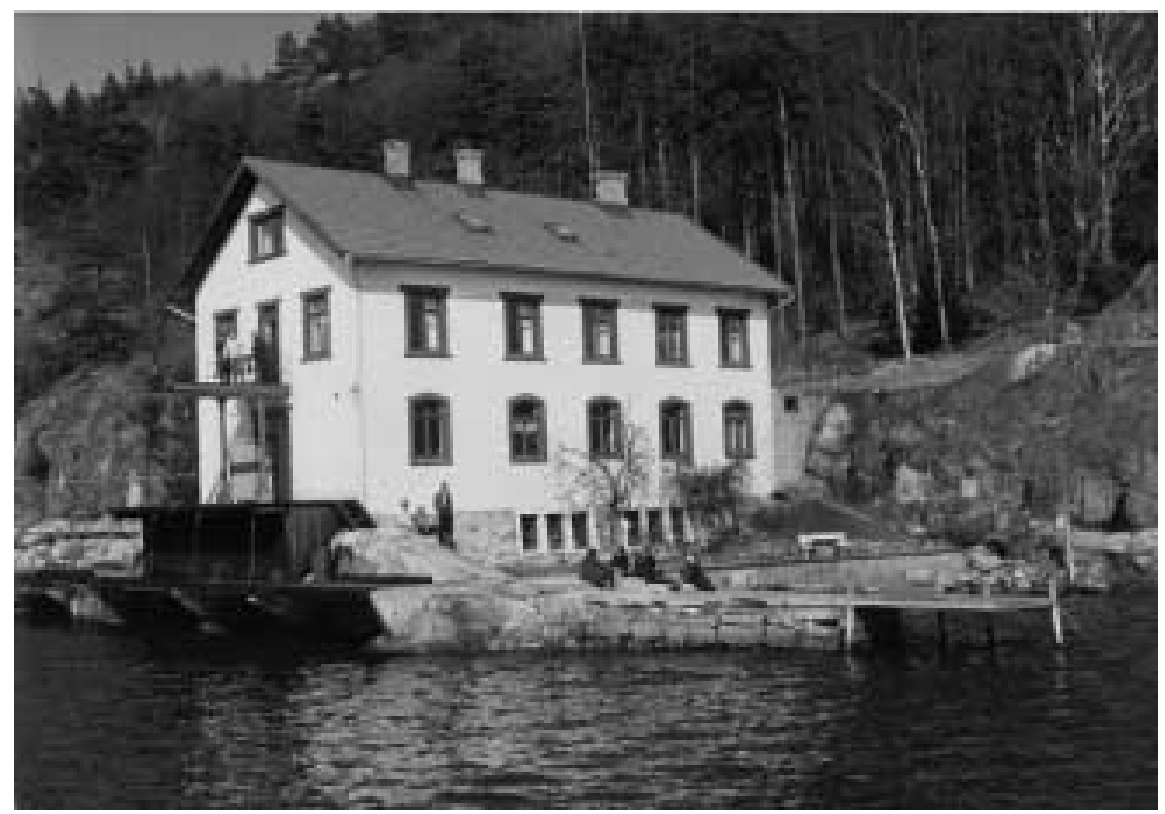

Fig. 4. The Bornö Hydrographic Station in the Gullmarsfjord. 
in the depth of the halocline with the help of daily measurements at the Bornö Station. He also constructed a photographically registering current meter in 1911, which worked excellently. The working time was 2 weeks (Svansson, 1996). Another well-known current meter was constructed by the son of F. L. Ekman, Prof. V. W. Ekman, in 1905. He also published an important theoretical contribution, the "Ekman spiral" (Ekman, 1906).

The HBC was operating the lightship measurements, published the daily measurement data, and carried also out different kinds of hydrographic and biological investigations in the waters around Sweden. Before WW I only temperature, salinity, and dissolved oxygen were reported on a routine basis. All years were not covered and for most years only one series of results exists for the main deep stations. After WW I we find in addition alkalinity and $\mathrm{pH}$ in the data reports. The work had still to be carried out by hand. Because of the slow work and few available research vessels, we mostly find only one observation series per year. A large gap in the observations in the open sea exists for the war years from 1914 to 1921. In 1935 the old Skagerak was replaced by a new ship, also named Skagerak (Fig. 5). Another long gap in observations was caused by WW II from 1939 to 1950. Because of the scarce

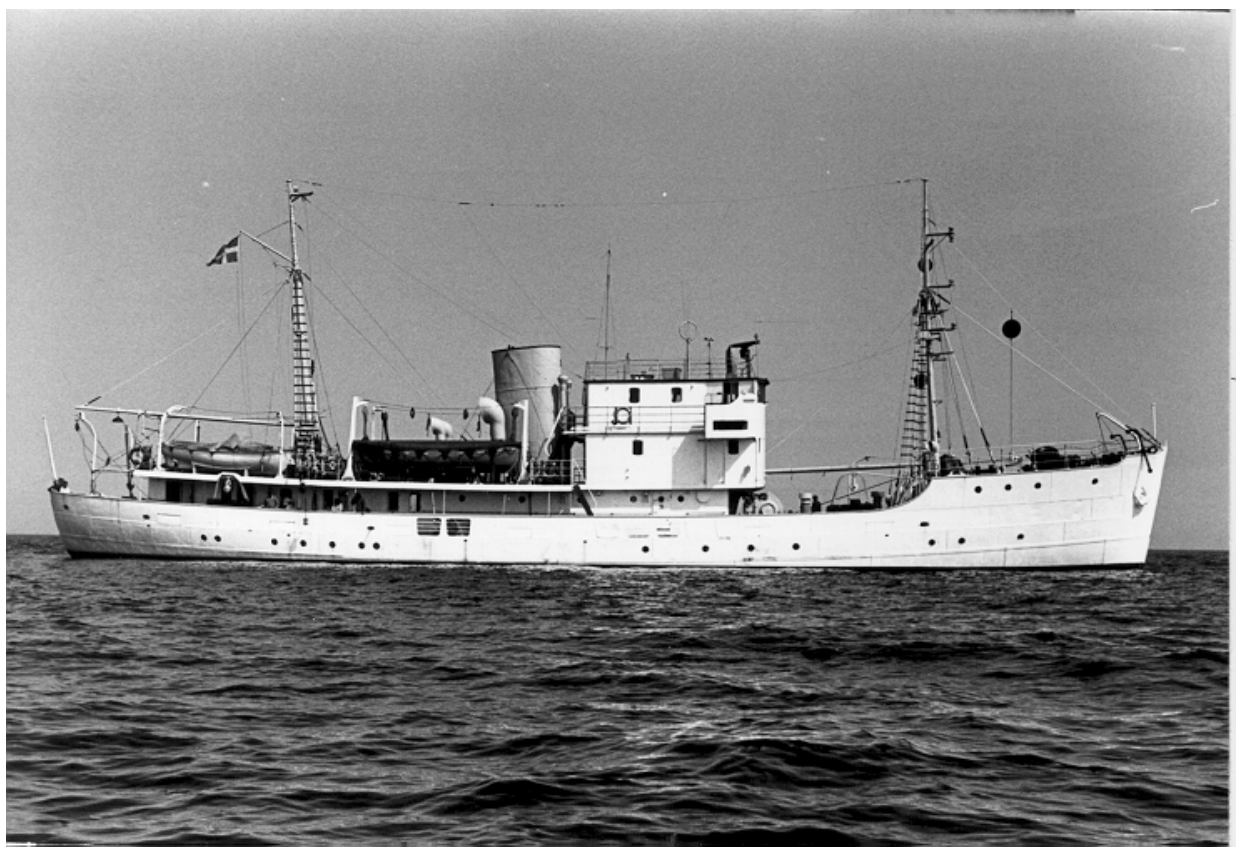

Fig. 5. The second R/V Skagerak 1935-1973. 
series of observations it was difficult to draw conclusions on the secular changes of salinity and oxygen.

Besides the Commission, the Fisheries Bureau at the Department of Agriculture carried out smaller investigations in fisheries and hydrography using a small fishing vessel, the Eystrasalt, which during the wars worked mainly in the Gulf of Bothnia.

\section{THE OCEANOGRAPHIC INSTITUTION AT THE UNIVERSITY AND THE OCEANOGRAPHIC INSTITUTE}

Göteborg was earlier a merchant city with wealthy shipyard owners, large shipping companies, factories, etc. The city has been dominated by some very rich families, who have supported art and literature. The University of Göteborg was from the beginning a private "high school", founded by donations. In Sweden a high school is a kind of university where some important faculties are missing. Many of the public buildings in Göteborg have been built with the help of donations.

In 1914 the Oceanographic Institution (OIU), including a docent's (assistant professor) position, was founded at the University through a donation by

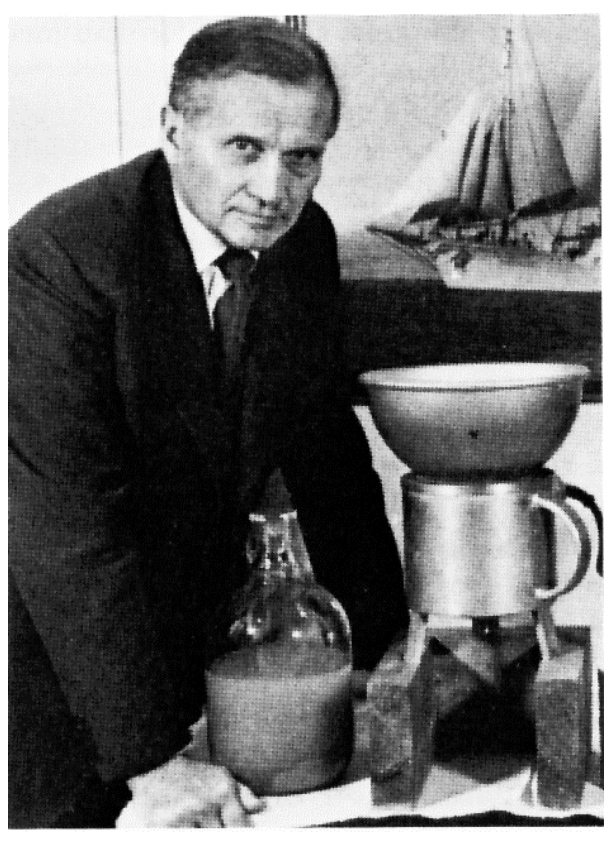

Fig. 6. Professor Hans Pettersson (1888-1966)
Mr. G. Ekman, oceanographer and industrialist. The son of O. Pettersson, Dr. Hans Pettersson (Fig. 6) was appointed docent at the institution, but he worked also as a hydrographic assistant at the HBC. The institution was located in two small rooms in the attic of the High School (University) building (another donation), where also the hydrographers of the Commission worked in wintertime, when the Bornö Station could not be used. In 1930 H. Pettersson was appointed full professor in oceanography through a new donation.

The Oceanographic Institute (OI) was established at Stigbergstorget in Göteborg in 1938 through a donation and was administrated by the Society of Sciences and Literature 
of Göteborg. The premises occupied three floors, with a workshop, a $17 \mathrm{~m}$ long water trench for current studies and a flat for the janitor's family on the ground floor. On the first floor was the library and offices for scientists, and on the second floor were laboratories, etc. A $12 \mathrm{~m}$ high plankton tower extended through all the three floors. It had a diameter of $2 \mathrm{~m}$ and could contain $37 \mathrm{~m}^{2}$ water. Unfortunately, it was built as a supporting part of the building. When the tower was filled with water, cracks appeared in the walls of the building and many doors could not be opened. The OI was a pure research institute and should not be confused with the OIU, which belonged to the High School and lectured on physical oceanography.

Prof. Hans Pettersson was appointed also director of the OI and the personnel of the OIU was relocated to the OI building together with the hydrographers of the HBC. He also was head of the hydrographic part of the HBC, member of its governing board and director of its Bornö Station until 1948. This caused much confusion and it is not easy to distinguish between the work carried out by the staff of the OIU, the OI, or by the HBC, because mostly the personnel worked part-time at all three organizations and took part in the ship expeditions. As I mentioned above, Pettersson, being leader of all three organizations, had a key position. The scientists employed by the Commission could simultaneously do research at the OI and technicians certainly analysed samples taken at routine cruises for the Commission and samples taken by the OI scientists. Professors had still in the 1930s very much power and Prof. Pettersson could do just what he wished.

Prof. Pettersson constructed in 1934 a transparency meter and studied transparency in sea water. His main interest was radioactive dating of sediments. Pettersson and his co-workers developed methods for radium analysis in sediments (Pettersson, 1930). He analysed together with E. Føyn, B. Karlik, and E. Rona the radioactivity of sea water (Føyn et al., 1939). N. Jerlov continued and developed Pettersson's optical studies and published two books on optical oceanography. A world-famous instrument is the deep sea piston corer, which was constructed in 1946 by B. Kullenberg. With this corer up to $20 \mathrm{~m}$ long cores could be taken from the ocean floor (Kullenberg, 1947). He was also famous for detecting and measuring inertial currents in the Baltic Sea (Gustafson \& Kullenberg, 1936).

These are some examples of the influence of Swedish scientists from the Baltic Sea area on the development of oceanographic research. From the 1930s the following world famous scientists worked at the OI and at the hydrographical part of the HBC: Prof. Hans Pettersson (director of the OI and member of the board of the HBC), Dr. Börje Kullenberg (docent at the OIU and first assistant at the HBC, physical oceanography, deep sea coring), 
Dr. Nils Jerlov (assistant at the HBC, marine optics), and Dr. Fritz Koczy (guest scientist, marine radioactivity).

Through a new donation Prof. Pettersson could arrange the Swedish Albatross expedition round the world in 1947-48 (Fig. 7). All leading hydrographers participated in the expedition. Pettersson was chief scientist, Kullenberg worked with deep-sea coring, Jerlov with optical measurements and hydrography, and Koczy with radioactivity measurements and chemistry. The cruise lasted for two years. Dr. Stina Gripenberg from Finland acted during the expedition as director of the OI. The "High School" was in 1954 taken over by the government and was now named the University of Göteborg. Many famous oceanographers worked in the OI. Among these Dr. Taivo Laevastu, now professor in the USA, an Estonian refugee, should be mentioned.

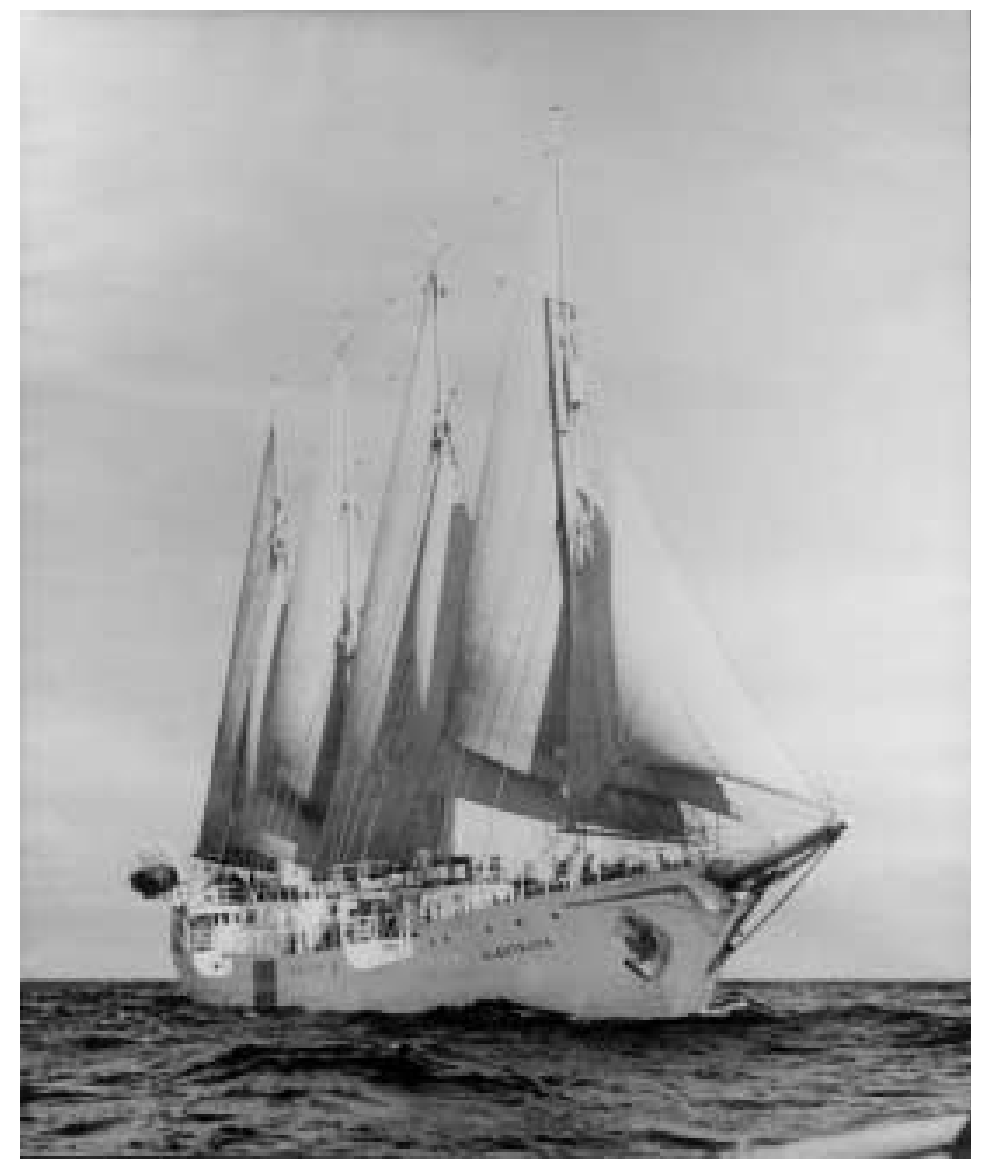

Fig. 7. The expedition ship Albatross. 
In 1961 the OI was merged with the OIU under the name of Oceanographic Institution. During the 1970s the University got an old fishing trawler, the Svanic, which was rebuilt into a small research ship with a crew of two and space for some eight teachers and students.

A few years ago the Oceanographic Institution was included into the Institution of Geosciences and was moved to a new building at Wavrinskys plats. In 1993 the institution got a small research vessel, a new Skagerak (the third Swedish R/V with the same name), which replaced the old Svanic.

A list of the professors, associated and assistant professors of oceanography in Göteborg and Stockholm and senior scientists in hydrography in Göteborg is given in Table 2 .

Table 2. Professors of oceanography in Göteborg and Stockholm and senior scientists in hydrography in Göteborg

\section{University of Göteborg \\ Professors}

Hans Pettersson 1930-56

Börje Kullenberg 1956-72

Pierre Welander 1972-75

Gunnar Kullenberg 1977-80

Gösta Walin, 1980-

University of Stockholm

Professors

Gary Shaffer 1989-92

Peter Lundberg 1993-
Associated professors, assistant professors

Börje Kullenberg 1948-56, Fritz Koczy 1955-57

Nils Jerlov 1957-63, Pierre Welander 1964-72

Gösta Walin 1972-77

Gösta Walin 1977-80

Anders Stigebrandt 1986-

Hydrographic Department 1948-79

Directors

Senior Scientists

Nils Jerlov 1948-57

Fritz Koczy 1948-55

Artur Svansson 1957-79

Stig Fonselius 1959-79

Institute of Hydrographic Research 1979-85

Director

Senior Scientist

Stig Fonselius 1979-85

Artur Svansson 1979-85

SMHI, Oceanographic Laboratory 1985-

Directors

Stig Fonselius 1985-87

Stig Carlberg 1987-91

Björn Sjöberg 1991-2000

Bertil Håkansson 2000-
Senior Scientists

Stig Carlberg

Elisabet Fogelqvist, Lars Edler

Michael Krysell, Mats Ohlson, Lars Edler

Elisabeth Sahlsten, Mats Ohlson, Lars Edler, Karin Borenäs 


\section{REORGANIZATION OF HYDROGRAPHIC RESEARCH IN SWEDEN}

In 1948 Swedish oceanography was reorganized. This happened during the Albatross expedition. A new Board of Fisheries was established, which took over the duties of the HBC. The HBC and the Fisheries Bureau were dissolved. Prof. Pettersson and Dr. Kullenberg remained as the scientific staff of the OI and the OIU. The remaining hydrographic staff of the HBC, Dr. Jerlov, Dr. Koczy, and two laboratory technicians, were transferred to the new Board of Fisheries as a Hydrographic Department, but were still housed in three rooms at the OI. The research ships Skagerak and Eystrasalt and the Bornö Hydrographic Station were transferred to the Board of Fisheries (Fig. 8).

The result of all this confusing reorganization was that the OIU and the OI together with the Hydrographic Department of the Board of Fisheries still were working in the same building and that in the beginning the OIU and the OI did not have any research vessel.

ORGANIZATION OF HYDROGRAPHIC RESEARCH IN SWEDEN

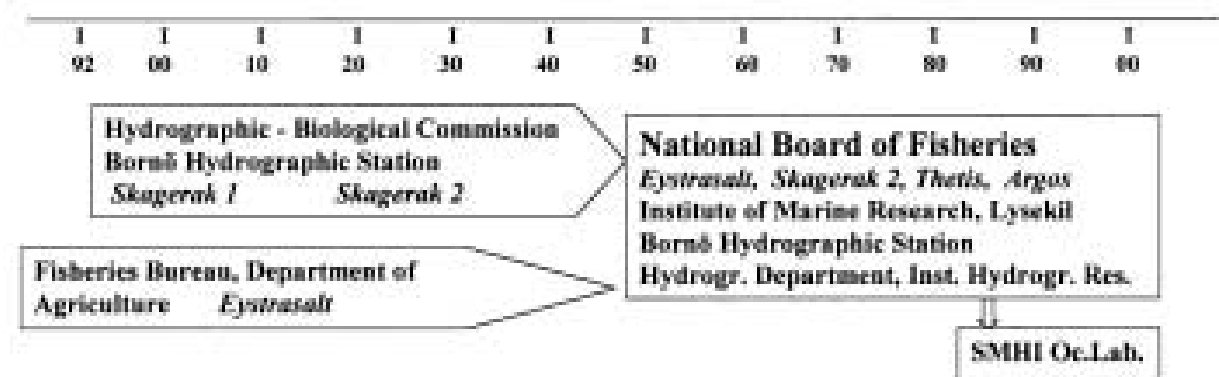

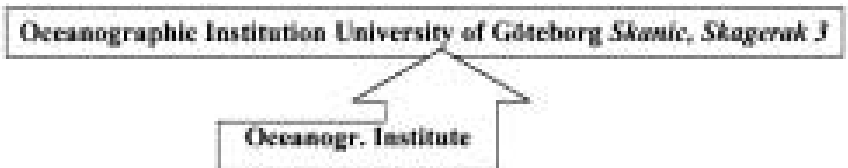

Navy Hydrogr, Oriee Oriew

Fig. 8. Scheme of the different oceanographic organizations in Sweden 1892-2000. 


\section{NATIONAL BOARD OF FISHERIES AND THE HYDROGRAPHIC DEPARTMENT}

The administration of the new Board of Fisheries was located in Göteborg. The biological part of the Commission, named the Institute of Marine Research, remained in Lysekil. It was difficult to decide where to move the hydrographers. It was considered that the High School (University) did not have a Faculty of Natural Sciences and therefore no competence to manage a hydrographic laboratory and routine work at sea. This is hard to understand because the High School did have an Oceanographic Institution and a professor in oceanography. But Prof. Pettersson was away on the Albatross expedition and was obviously not consulted at all. I will not here describe Prof. Pettersson's reaction when he got the news out at sea. The hydrographic part was temporarily located at the Oceanographic Institute in Göteborg with Dr. Jerlov as head, but as the Hydrographic Department of the new Institute of Marine Research in Lysekil.

The hydrographers of the Board of Fisheries had to carry out all open sea hydrographic work and research. A new smaller research ship, the Thetis, was built in 1967 and in 1974 the Skagerak was replaced with the new and larger R/V Argos (Fig. 9). The Hydrographic Department was relocated in new

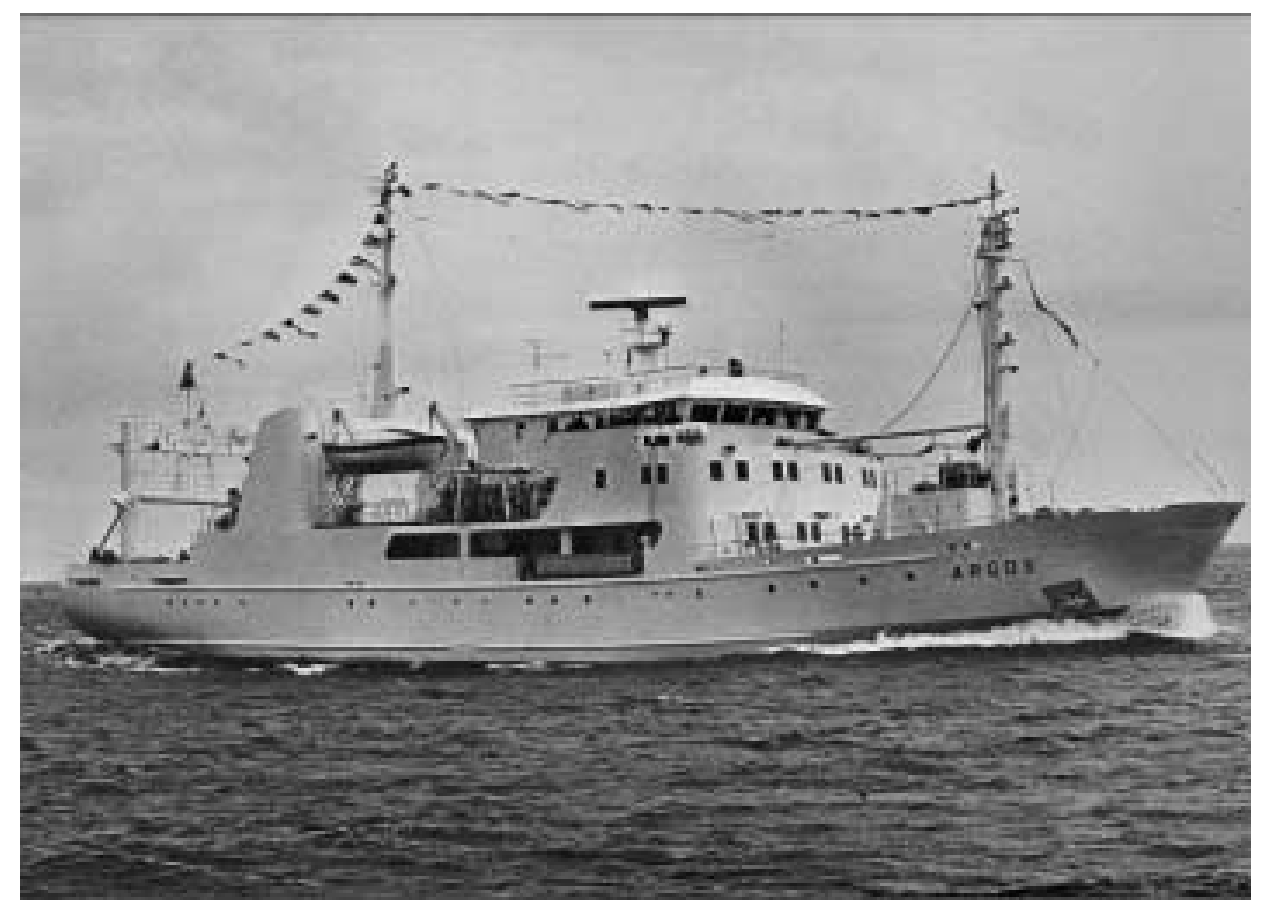

Fig. 9. The R/V Argos. 
laboratories in 1968, first at Stigbergsliden and later at Magasinsgatan. In 1979 the Hydrographic Department was separated from the Institute in Lysekil and became an independent Institute of Hydrographic Research. Because of the financial situation in Sweden during the 1980s the Thetis and the Eystrasalt were sold and the Bornö Hydrographic Station was closed. In 1985 the Institute was transferred to the Swedish Meteorological and Hydrological Institute as the SMHI Oceanographic Laboratory.

\section{THE NAVY HYDROGRAPHIC OFFICE}

Since WW II the Swedish Naval Forces had a small Hydrographic Office in Stockholm, consisting of a hydrographer and 3-4 assistants. The Office used a small fishing vessel, the Orion, which carried out measurements of temperature and salinity during the 1950s. The office cooperated closely with the Hydrographic Department of the Board of Fisheries. The salinity samples were analysed at the laboratory of the Hydrographic Department. One of the assistants was placed in Göteborg at the Hydrographic Department and, generally, navy hydrographers participated in the cruises of the Skagerak. The Navy Hydrographic Office was closed in 1985.

\section{THE HYDROGRAPHIC WORK AFTER WW II}

When the hydrographic work started after WW II around 1950, the difficulties were enormous. The research ship Skagerak was in bad condition. It had an experimental hot steam engine, which caused many problems. During the war it had been used as an auxiliary cruiser, actually the only Swedish man of war that managed to shoot down an intruding airplane with its only gun. Because of the war and the condition of the Skagerak hardly any hydrography was carried out in Sweden during the 1940s and the early 1950s. The hydrographers who participated in the Albatross expedition were mainly occupied with the preparations for the expedition and after the expedition with processing and publishing the scientific results.

The Hydrographic Office of the Swedish Navy, however, measured temperature and salinity at certain deep stations. Dr. Koczy moved to the Oceanographic Institute in 1955 and Dr. Jerlov was appointed associated professor there in 1957. Artur Svansson replaced first Koczy as assistant and then Jerlov as head of the Hydrographic Department and the author moved in 1959 to the laboratory 
as hydrographic assistant. The laboratory equipment was old-fashioned and most necessary glassware was lacking. The staff consisted of A. Svansson (director), S. Fonselius (hydrographic assistant), two laboratory technicians, and S. Engström (Navy hydrographic assistant). Because we were only five persons in the laboratory, we hardly had any time for using the Bornö Station. The work at sea and processing and publishing the results took all our time. Dr. Svansson and I also were members of the Hydrography Committee of the ICES and senior scientists at the Conference of Baltic Oceanographers. Field work could now be started slowly. The Skagerak was modernized in 1959-60 and got a diesel engine. In 1960 we also obtained a spectrophotometer and some glassware from the Lysekil laboratory, when their Technical Section was closed. Routine analysis of phosphate was introduced and some years later routine analysis of nitrite and nitrate. Later also analyses of silicate and ammonia were added.

A very large inflow of salt water to the Baltic Sea occurred in 1951, causing a stagnation period in the Gotland Deep, which lasted until 1961 (Fig. 10). This was something new in the Baltic research and started an intensive study of

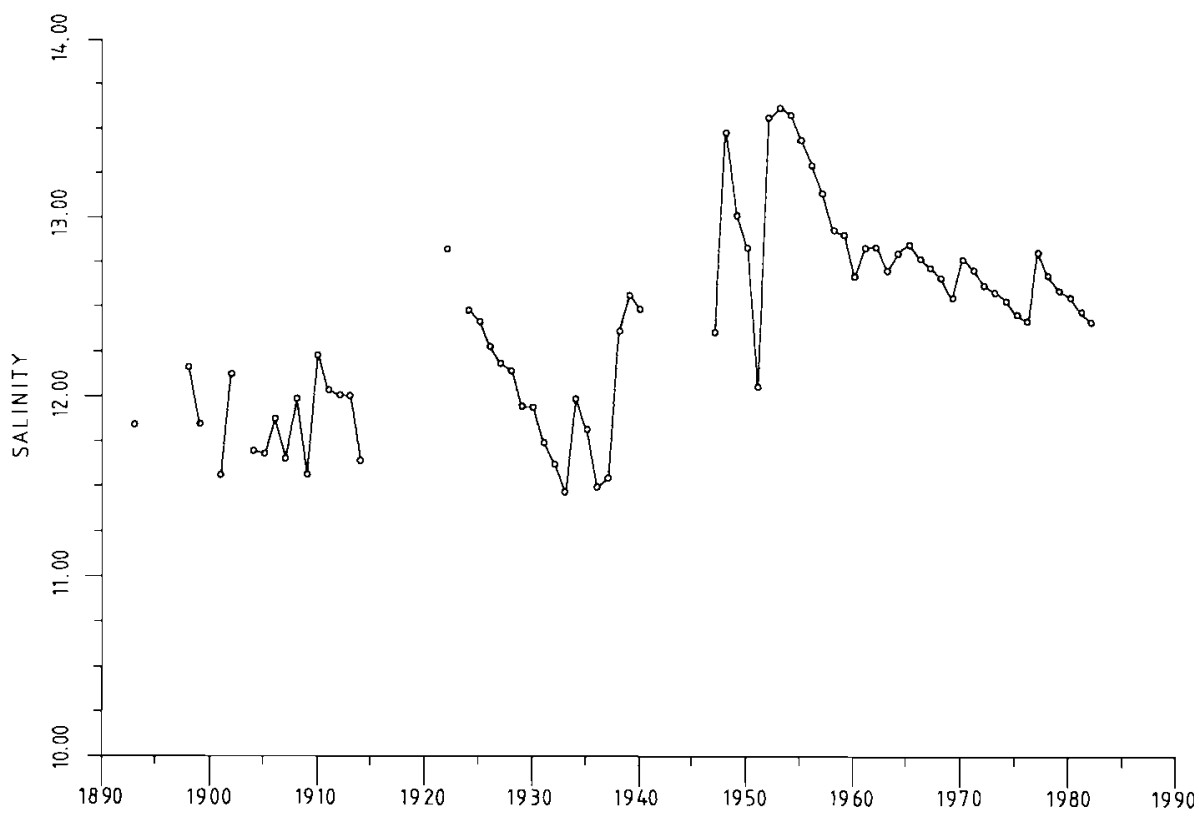

Fig. 10. Diagram showing the annual mean values of salinity (\%o) at $200 \mathrm{~m}$ in the Gotland Deep from 1892 to 1985 . 


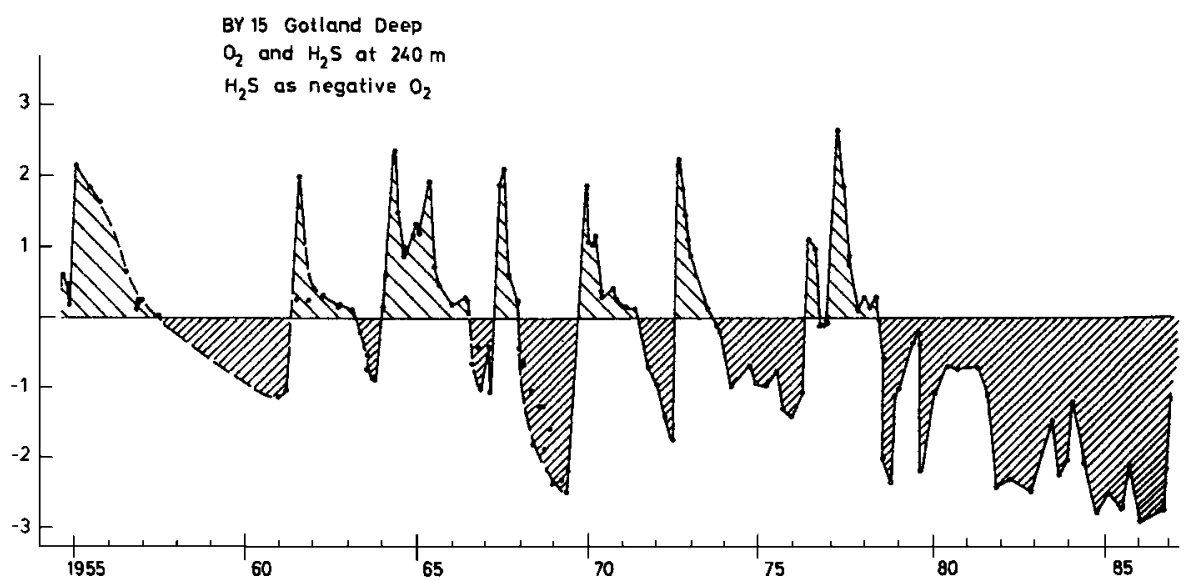

Fig. 11. Variations in oxygen and hydrogen sulphide content $(\mathrm{ml} / \mathrm{L})$ in the deep water at $240 \mathrm{~m}$ in the Gotland Deep in 1954-87. Hydrogen sulphide shown as negative oxygen according to Fonselius (1969).

the chemical changes in the deep water. We could show the decreasing trend of oxygen and formation of hydrogen sulphide in the deep water (Fonselius, 1969). Cooperative programmes were introduced (Dybern \& Fonselius, 2001). The amount of routine hydrographic data increased enormously due to new faster standard methods. Long-term results for salinity, temperature, oxygen (Fig. 11), and later nutrients could be worked out, and we could demonstrate the increasing nutrient trends in the Baltic Sea. In the beginning the Board of Fisheries refused to give us grants for pollution studies. The administrators stated that fish did not swim in polluted waters! However, in 1967 we got research grants for pollution studies, mainly from the Swedish Environment Protection Board. The staff could be increased and was in 1985 around 15 persons. New and modern instruments were purchased by means of research grants.

Modelling of water, salt, and nutrient balances could now be carried out. The introduction of electronic equipment for sampling and calculations and later of computers speeded up the scientific work both on board ships and in the shore laboratories. Autoanalysers for the determination of nutrients and several other parameters were introduced. The laboratory is since 1986 located at Nya Varvet (the former Navy Base) at the shore of the Göta River in modern and adequate premises (Fig. 12). Table 2 shows the directors and senior scientists at the different stages of the laboratory. 


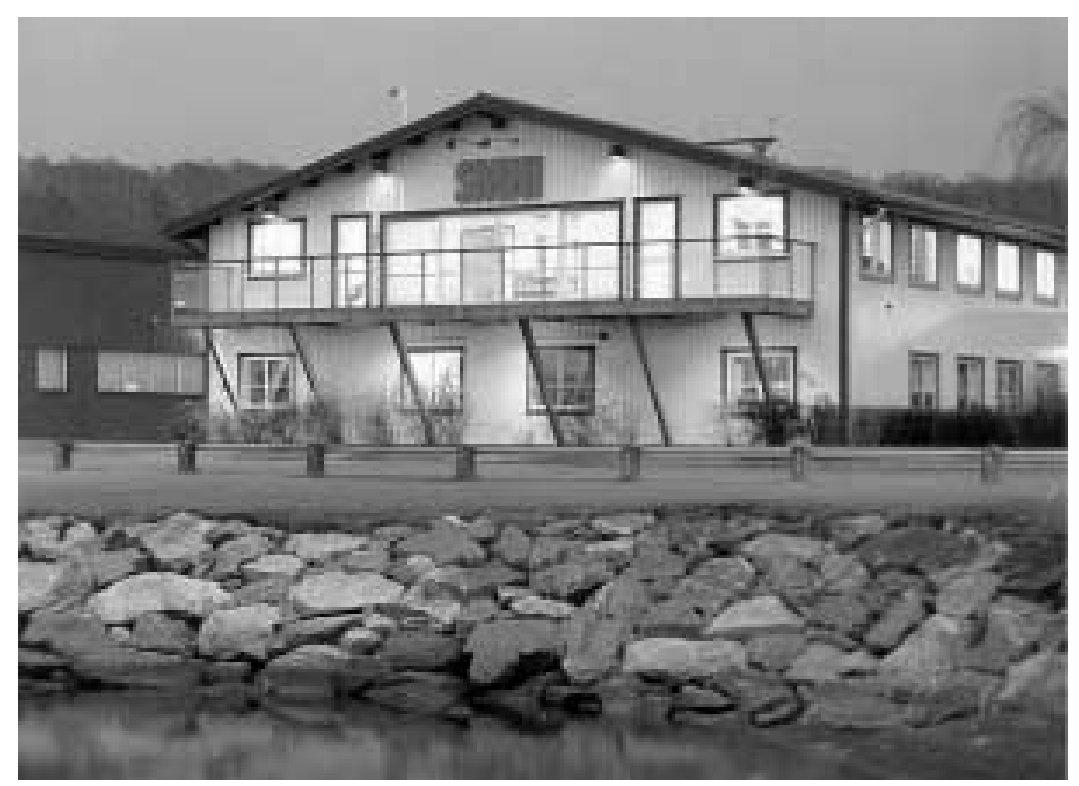

Fig. 12. The SMHI Oceanographic Laboratory at Nya Varvet, 2001.

\begin{abstract}
SUMMARY
Sweden has never had a real governmental Marine Research Institute covering all fields in physical, chemical, biological, and sedimentological oceanography. The Hydrographic-Biological Commission worked mainly with hydrography and biological problems of fisheries. The Oceanographic Institution at the University taught physical oceanography. The Oceanographic Institute really had competence for work with many kinds of marine problems but it was too small, it lacked funds, and its very small staff was not capable of handling many tasks. In 1961, when the Institute was merged with the University Institution, the chemical, biological, and sedimentological problems were taken over by other University institutions. The biological part of the Commission was a fisheries research institute and continued with these tasks when it was taken over by the Board of Fisheries. The Hydrographic Department was a part of the Board of Fisheries and its main task was to provide the Fisheries Laboratory in Lysekil and the fishermen with hydrographic information. In the beginning mapping of oxygen free bottoms was the most important task, but with the help of research grants the Laboratory could extend its activities to nutrient measurements, etc. Its successor,
\end{abstract}


the SMHI Oceanographic Laboratory works mainly with general open sea sampling and marine physical and chemical problems.

No real coordination of the hydrographic research exists in Sweden. The Argos is the only Swedish research vessel which is capable of working in the open sea during severe conditions and for several weeks. It belongs to the Board of Fisheries and is mainly used for fisheries research and for hydrography carried out by the Oceanographic Laboratory. If we had a central Marine Research Institute, which also could administrate and operate a pool of research ships, these could be used in a much more rational way.

\section{REFERENCES}

Anon. 1878. Nautisk-meteorologisk Konference i Kjobenhavn mellem Delegerede fra Norge, Sverige og Danmark Oktober 1878.

Anon. 1879. Instruktion för hydrografiska observationers utförande vid svenska fyr- och lotsstationer. Nautisk-meteorologiska byrån (Stockholm), No. 5. Kungliga Boktryckeriet P. A. Nordstedt \& söner, Stockholm.

Anon. 1892. Det 14 Skandinaviske Naturforskermøde. J. Jørgensen \& Co, Kjøbenhavn.

Bergman, T. O. 1788. Physical and Chemical Essays, 3. J. Murray, London (in Latin).

Bladh, P. J. 1776. Svenska Vetenskapsakademiens Handlingar, 37, p. 324.

Cronander, A. W. 1898. On the Laws of Movement of Sea-currents and Rivers. Norrköpings Tidningars A. B. Norrköping.

Dybern, B.-I. \& Fonselius, S. 2001. International marine scientific activities in the Baltic Sea with special reference to Estonian participation. Proc. Estonian Acad. Sci. Biol. Ecol., 50 (in press).

Ekman, F. L. 1893. Den svenska hydrografiska expeditionen år 1877, Första avd. Kungl. Sv. Vetenskapsakad. Handl., 25, 1, 3-72.

Ekman, V. W. 1906. Ann. D. Hydrographie u. Marit. Meteorologie, 34, 423-430.

Fonselius, S. 1969. Hydrography of the Baltic Deep Basins III. Fishery Board of Sweden, Ser. Hydrography, No. 23.

Fonselius, S. 2001. Hydrographical investigations in the Baltic Sea area before the founding of ICES. ICES Marine Science Symposia (in press).

Føyn, E., Karlik, B., Pettersson, H. \& Rona, E. 1939. Göteborgs Kungl. Vetensk. o. Vitterh. Samh. Handl. (Medd. Oceanogr. Inst. Göteborg), 5, Ser. B: 6, No. 12.

Gustafson, T. \& Kullenberg, B. 1936. Untersuchungen von Trägheitsströmungen in der Ostsee. Sv. Hydrogr.-Biol. Komm. Skr. Ny ser. hydrogr., XIII.

Kullenberg, B. 1947. The piston core sampler. Sv. Hydrogr.-Biol. Komm. Skr. Ser. Hydrogr., I.

Nordenanckar, J. 1795. Om strömningarna i Östersjön. Föredrag för Kungl. Vetensk. Akad. $i$ Stockholm den 18 januari 1792.

Pettersson, H. 1930. Teneur en radium des depôts de mer profonde (Princesse-Alice et Challenger). Rés. Camp. Sci. Monaco, Fasc. 81, pp. 1-50. Impr. Principauté.

Pettersson, O. 1893. Resultaten av den svenska hydrografiska expeditionen år 1877. Kungl. Sv. Vetenskapsakad. Handl., 25, 73-161.

Pettersson, O. \& Ekman, G. 1897. Kungl. Sv. Vetenskapsakad. Handl., 29 (5). 
Svansson, A. 1996. Vikarvets årsberättelse 1994-1995, pp. 106-114.

Wilcke, J. K. 1771. Beskrivning på ett instrument att upphämta vatten ifrån större djup utur hafvet med rön om hafsvattnets värma och tyngd på olika djup i Öresund. Kungl. Sv. Vetenskapsakad. Handl., 32, 60-66.

\section{ROOTSI HÜDROGRAAFILISTE UURINGUTE AJALUGU}

\section{Stig FONSELIUS}

Läänemere vee koosseisu ja omadusi Rootsi rannikumere eri osades hakati selgitama 18. sajandil. Regulaarsed vee temperatuuri, soolsuse ja hoovuste mõõtmised Rootsi tulelaevadel ja rannikupunktides algasid 1878. aastal. Läänemere uuringutest on osa võtnud paljud kuulsad Rootsi mereteadlased. Mere- ja kalandusuuringute korraldus ja vastavate asutuste ülesanded ning omavahelised suhted on pidevalt evolutsioneerunud alates Rootsi hüdrograafiakomisjoni loomisest 1893. aastal kuni tänapäevani. 